\title{
METAFORA TUMBUHAN DALAM PERIBAHASA INDONESIA (KAIIAN SEMANTIK KOGNITIF)
}

\author{
Kingkin Puput Kinanti dan Anita Kurnia Rachman \\ Budi Utomo Malang \\ kingkinkinanti13@yahoo.co.id. \\ Diterima: 3 Maret 2018 \\ Publikasi: 27 Februari 2019 \\ DOI: http://dx.doi.org/10.32528/bb.v4i1.1867
}

\begin{abstract}
ABSTRAK
Penelitian ini merupakan penelitian tentang peribahasa Indonesia yang berkaitan dengan penggunaan metafora tumbuhan. Penelitian bertujuan untuk menemukan beberapa hal, yaitu 1) penggunaan nama-nama tumbuhan dalam peribahasa Indonesia, 2) menemukan intepretasi metafora tumbuhan dalam peribahasa Indonesia. Data berupa data tertulis yang diambil dari kamus peribahasa Indonesia karya JS. Badudu dan buku kumpulan peribahasa karya Mohammad Kusnadi Wasri. Keseluruhan peribahasa dalam buku kumpulan peribahasa tersebut disimak, dikumpulkan, dan diseleksi sesuai topik permasalahan, yaitu peribahasa yang menggunakan nama-nama tumbuhan. Selanjutnya data diklasifikasikan berdasarkan jenis-jenis tumbuhan dan hal-hal yang diacu. Data dikumpulkan dengan metode simak diikuti dengan teknik simak bebas libat cakap (SBLC). Analisis data menggunakan metode intepretatif dan wawancara kepada ahli bahasa dengan pisau bedah teori semantik kognitif. Hasil penelitian menunjukkan bahwa terdapat nama-nama tumbuhan yang digunakan dalam peribahasa, yaitu 1) bagian-bagian tumbuhan meliputi biji, akar, batang, dahan, daun, dan bunga; 2) klasifikasi tumbuhan berdasarkan bijinya, yaitu tumbuhan dikotil dan tumbuhan monokotil. Tumbuhan dikotil meliputi delima, kacang, kopi, nangka, ubi, cabai, cempedak, durian, limau, dan lada; sedangkan tumbuhan monokotil yaitu bambu, mentimun, padi, rumput, tebu, mawar, pisang, jagung, kelapa, kunyit, dan sirih. Intepretasi makna metaforis peribahasa menggunakan nama tumbuhan yaitu, peribahasa yang menggambarkan tumbuhan sebagai kekuatan dan kelemahan, menggambarkan tumbuhan sebagai tanda sifat terpuji, tumbuhan sebagai tanda rejeki, tumbuhan sebagai tanda hidup sederhana, dan tumbuhan sebagai tanda keburukan.
\end{abstract}

Kata kunci: peribahasa, metafora, tumbuhan

\begin{abstract}
This research is about Indonesian idiom conected with the using of plant metaphorical. It is aimed to find some subjects, these are; 1) the using of the name of the plants in Indonesian idiom, 2) finding plant metaphorical interpretation in Indonesian idiom. The data used is written data from Indonesian idiom dictionary by JS. Badudu and the book collection of idiom by Mohammad Kusnadi Wasri. All the idiom in the idiom book collections are seen, collected, and selected based on the topic that is the idiom which uses the plant names. After that, the data are classified based on the kinds of plants and everything about plants. The data is collected with seen method followed by free seen and talked. The analysis of the data used interview and interpretatif method with the language expert with cognitif semantic theory analysis Great Chain Metaphore Theory. The result showed there are plant names used in the idiom, those are; 1) the parts of the plant consist of seeds, roots, stems, branches, leaves, and flowers, 2) Plant classifcation based on the seed are dikotil and monocotil. Dicotil plant includes pomegranate, nuts, coffee, jackfruit, yam, chili, "cempedak", "durian", limes, and
\end{abstract}




\begin{abstract}
pepper; while monocot plants are bamboo, cucumber, rice, grass, sugar cane, roses, bananas, corn, coconut, turmeric, and betel. The interpretation of the metaphorical meaning of the maxim uses the name of the plant that is, the proverb describing the plant as a sign of strength and weakness, the plant as a sign of commendable nature, plants as a sign of fortune, plants as a sign of simple living, and plants as a sign of evil. Key word: idiom, plant methaporical, cognitive semantic
\end{abstract}

\section{PENDAHULUAN}

Indonesia merupakan negara dan bangsa yang kaya akan budaya. Budaya Indonesia membawa nilai-nilai luhur yang dimiliki oleh bangsa. Salah satu budaya luhur yang dimiliki oleh bangsa Indonesia adalah peribahasa. Peribahasa Indonesia berisi perbandingan, perumpamaan, nasihat, prinsip hidup atau aturan tingkah laku yang menjadi kebijaksanaan lokal bagi suatu masyarakat.

Peribahasa dikatakan sebagai salah satu cerminan cara berpikir masyarakat Indonesia. Hal ini senada dengan pernyataan Sibarani (2004:61) bahwa setiap pembentukan kata-kata bahkan kalimat dalam suatu bahasa (termasuk yang dipakai dalam peribahasa) dapat menentukan sifat atau ciri pikir dalam kebudayaan suatu bangsa sedangkan Danandjaya (1984:21-28) menyatakan bahwa peribahasa merupakan salah satu bentuk foklor yang merupakan intisari dari pengalaman suatu penutur bahasa.

Peribahasa dari beberapa penelitian yang pernah dilakukan menggunakan beberapa leksikon, seperti leksikon tumbuhan, hewan, benda mati, kosmos, dan manusia. Penggunaan nama-nama tersebut merupakan salah satu dari penggunaaan bahasa figuratif dan harus dimaknai dengan makna figuratif. Makna figuratif adalah makna bentuk kebahasaan yang menyimpang dari referennya (Wijana, 2008:24). Hal ini seperti penyataan Pateda (2001:108) bahwa peribahasa merupakan representasi dari penggunaan makna figuratif.

Salah satu hal yang menarik dalam peribahasa Indonesia adalah penggunaan nama tumbuhan. Indonesia memang terkenal sebagai negara yang memiliki tanah yang subur sehingga tumbuh beraneka ragam tumbuhan. Hal ini membuat nama tumbuhan yang digunakan dalam peribahasa Indonesia juga sangat bervariasi. Beberapa nama tumbuhan yang digunakan seperti padi, daun talas, cendawan, rotan, ubi, benalu, pisang dan sebagainya. Berikut ini merupakan contoh dari penggunaan nama-nama tumbuhan dalam peribahasa Indonesia:

a. Ada beras taruh dalam padi "Rahasia hendaklah disimpan baik-baik."

b. Bagai air di daun talas. "Tidak memiliki pendirian"

c. Ada batang mati, adalah cendawan tumbuh.

"Dimana kita tinggal akan ada rejeki."

d. Ada rotan, ada duri "Dalam kesenangan, tentu ada kesusahannya."

e. Bagai rasa batang pisang. "Tubuh seseorang yang terlalu dingin." 
Penggunaan nama-nama tumbuhan tersebut merupakan aplikasi dari penggunaan bahasa figuratif. Salah satu jenisnya adalah metafora. Metafora seringkali digunakan untuk menjelaskan sesuatu yang abstrak agar lebih bersifat konkrit. Seperti peribahasa "Ada batang mati, adalah cendawan tumbuh" yang memiliki arti "Dimana kita tinggal akan ada rejeki". Batang mati dan cendawan menjelaskan tentang tempat tinggal dan rejeki yang dijelaskan secara lebih konkrit. Peribahasa "Ada rotan, ada duri" juga menunjukkan dua hal yang bersifat konkrit dan abstrak, yaitu kesenangan dan kesusahan yang bersifat abstrak dikonkritkan dengan rotan dan duri. Maka, dalam peribahasa dikenal dengan adanya dua domain, yaitu domain yang abstrak dan domain yang konkrit dimana kedua domain tersebut berkorespondensi satu sama lain. Penggunaan dua domain tersebut juga merupakan sebuah upaya membandingkan, menganalogikan leksikon tertentu dalam peribahasa menunjukkan bentuk pemetaforaan.

Teori metafora yang digunakan dalam penelitian ini adalah metafora konseptual atau metafora kognitif. Menurut Konvesces (2002:4), metafora konseptual adalah metafora yang berusaha menjelaskan salah satu ranah dengan ranah lain. Teori ini juga disebut teori metafora kognitif, karena dikembangkan oleh linguis kognitif, seperti Lakoff dan Johnson (1980) lewat buku Metaphor We Live By yang menghasilkan pandangan bahwa metafora menayangkan peta kognitif dari satu ranah pebanding kepada ranah pembanding sehingga menyebabkan pembanding terikat dalam pengalaman fisik spasial melalui ranah pebanding.

Metafora memiliki dua komponen, yaitu target dan sumber. Sumber merupakan konsep yang dijadikan dasar konseptualisasi dan target merupakan konsep dimana konseptualisasi diarahkan. Target biasanya lebih abstrak dan sumber lebih konkrit. Untuk dapat memahami maksud yang terkandung dalam metafora ditemukan kesamaan karakteristik yang dimiliki antara target dan sumber. Dengan membandingkan karakteristik yang dimiliki keduanya, maka ditemukan dasar suatu metafora digunakan. Selain itu kesamaan tidak selalu menjadi dasar untuk menunjukkan hubungan antara target dengan sumbernya, namun konseptualisasi yang berkorespondensi antara target dan sumberlah yang lebih ditonjolkan (Nirmala, 2014).

Pemetaforaan dalam peribahasa juga merupakan akibat dari tuntutan daya kreatifitas manusia agar ungkapan manusia tidak monoton. Hal ini merupakan ciri dari bahasa yang berfungsi sebagai sarana untuk menyampaikan keindahan. Metafora juga bertujuan untuk membuat bahasa lebih efektif karena pemakaian parafrase untuk menjelaskan sesuatu yang belum memiliki leksikon akan terkesan tidak ekonomis (Black dalam Bagea, 2013:1).

Dengan adanya penggunaan metafora dalam peribahasa Indonesia, khususnya leksikon tumbuhan, penelitian ini menjadi sangat menarik. Upaya untuk 
menemukan nama-nama tumbuhan yang digunakan dalam peribahasa Indonesia dan bagaimana intepretasi yang muncul dari penggunaan nama-nama tersebut akan memberikan gambaran bagaimana pola pikir masyarakat Indonesia dengan penggunaan nama-nama tumbuhan tertentu.

Penelitian berkaitan dengan peribahasa, metafora, maupun analisis semantik kognitif pernah dilakukan oleh beberapa peneliti.

Deli Nirmala (2014) melakukan penelitian dengan judul "Proses Kognitif dalam Ungkapan Metaforis" . Penelitian Nirmala menjelaskan bagaimana proses kognitif menghasilkan ungkapan metaforis. Hasil penelitian menunjukkan bahwa untuk menghasilkan ungkapan metaforis dilakukan strategi asosiatif dengan menunjukkan korespondensi antara ranah sumber dengan ranah sasaran. Penelitian Nirmala berbeda dengan penelitian ini. Penelitian Nirmala bersumber dari data random yang diambil dari berbagai sumber seperti percakapan, berita, dan bahasa surat kabar sedangkan penulis berfokus pada metafora tumbuhan dalam peribahasa Indonesia.

Penelitian yang menggunakan sumber peribahasa juga dilakukan oleh beberapa peneliti. Kurnia (2016) meneliti tentang peribahasa Jawa. Kajiannya berupa kajian semantik kognitif yang mencoba mengkaji metafora binatang. Namun penelitian ini memiliki kekurangan karena hanya menjelaskan satu peribahasa saja sehingga hasil penelitian kurang mendalam.
Resa Sindi Harja melakukan penelitian dengan judul "Bentuk dan Makna Peribahasa Bahasa Indonesia yang Terbentuk Oleh Unsur Tumbuhan, Jenis-Jenis Tumbuhan, dan Hal-Hal yang Berkaitan dengan Tumbuhan". Penelitian ini menjelaskan fungsi sintaksis yang diduduki oleh unsur, jenis, dan hal-hal yang berkaitan dengan tumbuhan dalam peribahasa Indonesia. Fokus penelitian Harja berbeda dengan yang akan penulis teliti yaitu menggunakan kajian semantik bukan sintaksis.

Penelitian lain berkaitan dengan peribahasa dilakukan oleh Resti Yulyasa, Ahmad Rabi-ul Muzammil, dan Agus Syahrani. Peneliti mengambil judul "Leksikon Nama Tumbuhan dalam Peribahasa Masyarakat Melayu Sekadau.". Penelitian ini menjelaskan bagaimana makna leksikal dan makna metaforis dari bagian tumbuhan yang digunakan dalam peribahasa. Fokus kajian yang digunakan adalah etnolinguistik.

Imron Ho-Abdullah dari Universits Kebangsaan Malaysia menulis artikel dengan judul "Analisis Kognitif Semantik Peribahasa Melayu Bersumber Anjing". Penelitian ini membahas bagaimana mekanisme kognitif manusia membentuk peribahasa yang melibatkan hewan, khususnya anjing dari pandangan semantik kognitif.

Melihat perbedaan dengan penelitian terdahulu, penelitian ini menjadi penting untuk dilakukan. Pertama, kajian semantik kognitif khususnya yang berkaitan dengan peribahasa perlu dilakukan untuk memperkaya kajian 
semantik dalam ranah ilmu linguistik. Kedua, penelitian mengenai leksikon tumbuhan menarik untuk dilakukan mengingat tumbuh-tumbuhan adalah salah satu entitas penting dalam kehidupan masyarakat Indonesia dimana setiap jenisnya mengandung ciri khas bangsa Indonesia.

\section{METODE PENELITIAN}

Penelitian ini merupakan penelitian semantik dengan fokus pada kajian semantik kognitif. Jenis penelitian adalah deskriptif kualitatif. Penelitian deskriptif karena penelitian akan dijelaskan dengan kata-kata. Objek penelitian adalah penggunaan metafora tumbuhan dalam peribahasa Indonesia. Peneliti melakukan beberapa hal, mulai pengumpulan data, analisis data, dan penyajian analisis data.

Data dalam penelitian ini adalah data tertulis yang diperoleh dari kamus peribahasa Indonesia karya J.S. Badudu dan buku kumpulan peribahasa karya Moh. Kusnadi Wasri.

Pengumpulan data tertulis dilakukan dengan cara mengambil data tertulis berupa peribahasa Indonesia. Bahan yang digunakan diambil dari kumpulan peribahasa Indonesia. Data dikumpulan dengan metode simak diikuti dengan teknik simak bebas libat cakap (SBLC). Keseluruhan peribahasa dalam buku kumpulan peribahasa tersebut disimak, dikumpulkan, dan diseleksi sesuai topik permasalahan, yaitu peribahasa yang menggunakan nama-nama tumbuhan. Selanjutnya data diklasifikasikan berdasarkan jenis-jenis tumbuhan dan ha-hal yang diacu. Setelah data diperolah dan dikumpulkan, data dianalisis dengan cara mengklasifikasikan berdasarkan ranah metafora yang digunakan. Metode analisis data adalah metode padan. Metode padan yaitu metode analisis data yang alat penentunya berada di luar, terlepas, dan tidak menjadi bagian dari bahasa yang diteliti. Analisis data selanjutnya adalah proses analisis mendalam dengan metode intepretasi atau penafsiran.

Penyajian analisis data dilakukan dengan bentuk narasi. Penyajian ke dalam bentuk narasi dibagi dua jenis, yaitu formal dan informal (Sudaryanto, 1993:145). Penyajian hasil analisis ini dilakukan secara informal karena penyajian analisis data dengan memakai kata-kata biasa yang mudah dimengerti dan dipahami.

\section{PEMBAHASAN}

\section{A. Nama-Nama Tumbuhan dalam} Peribahasa Indonesia

Terdapat kurang lebih 78 peribahasa Indonesia yang menggunakan namanama tumbuhan yang telah peneliti klasifikasikan berdasarkan buku kamus peribahasa karya J.S Badudu dan buku kumpulan peribahasa karya Mohammad Kusnadi Wasri. Nama-nama tumbuhan yang digunakan dalam peribahasa Indonesia diklasifikasikan menjadi dua, yaitu berdasarkan bagian-bagian tumbuhan dan klasifikasi berdasarkan bijinya (tumbuhan monokotil dan tumbuhan dikotil).

Klasifikasi peribahasa tumbuhan berdasarkan bagian-bagian tumbuhan 
meliputi biji, akar, batang/dahan, duri, daun, bunga, dan buah.

Tabel 1 Bagian-bagian Tumbuhan yang digunakan dalam Peribahasa Indonesia

\begin{tabular}{|c|c|c|}
\hline No. & $\begin{array}{l}\text { Bagian } \\
\text { Tumbuhan }\end{array}$ & Peribahasa \\
\hline 1. & Biji & $\begin{array}{l}\text { "Mengambil biji nangka } \\
\text { akan terkena getahnya" } \\
\text { "Manabur biji ke atas } \\
\text { batu" }\end{array}$ \\
\hline 2. & Akar & $\begin{array}{l}\text { "Tiada rotan, akarpun } \\
\text { berguna" } \\
\text { "Bergantung pada akar } \\
\text { lapuk" }\end{array}$ \\
\hline 3. & Batang/dahan & $\begin{array}{l}\text { "Dahan pembaji batang" } \\
\text { "Besar kayu besar } \\
\text { dahannya" }\end{array}$ \\
\hline 4. & Duri & $\begin{array}{l}\text { "Seperti duri dalam } \\
\text { daging" }\end{array}$ \\
\hline 5. & Daun & $\begin{array}{l}\text { "Pucuk dicita, ulam tiba" } \\
\text { "Seperti daun delima } \\
\text { dengan bunganya" }\end{array}$ \\
\hline 6. & Bunga & $\begin{array}{l}\text { "Jauh bau bunga, dekat } \\
\text { bau tahi" } \\
\text { "Ibarat bunga, sedap } \\
\text { dipakai layu dibuang" }\end{array}$ \\
\hline 7. & Buah & $\begin{array}{l}\text { "Sebab buah dikenal } \\
\text { pohonnya" } \\
\text { "Buah manis berulat di } \\
\text { dalamnya" }\end{array}$ \\
\hline
\end{tabular}

Klasifikasi tumbuhan berdasarkan bijinya dibagi menjadi dua, yaitu tumbuhan dikotil dan tumbuhan monokotil. Tumbuhan dikotil meliputi delima, kacang, kopi, nangka, ubi, cabai, cempedak, durian, lada, dan limau.

Tabel 2 Nama-nama Tumbuhan Dikotil yang digunakan dalam Peribahasa Indonesia

\begin{tabular}{|c|c|c|}
\hline No. & $\begin{array}{l}\text { Tumbuhan } \\
\text { Dikotil }\end{array}$ & Peribahasa \\
\hline 1. & Delima & $\begin{array}{l}\text { "Seperti daun delima } \\
\text { dengan bunganya" }\end{array}$ \\
\hline 2. & Kacang & $\begin{array}{l}\text { "Bila siang hari,lupa } \\
\text { kacang pada kulitnya" }\end{array}$ \\
\hline 3. & Kopi & "Mendapat kopi pahit" \\
\hline 4. & Nangka & $\begin{array}{l}\text { "Orang makan nangka, } \\
\text { awak kena getahnya" }\end{array}$ \\
\hline 5. & Ubi & $\begin{array}{l}\text { "Ada ubi ada talas" } \\
\text { "Seperti ayam } \\
\text { mendapatkan ubi" }\end{array}$ \\
\hline 6. & Cabai & $\begin{array}{l}\text { "Kecil-kecil cabai rawit" } \\
\text { "Siapa makan cabai akan } \\
\text { merasa pedas" }\end{array}$ \\
\hline 7. & Cempedak & $\begin{array}{l}\text { "Seorang makan } \\
\text { cempedak, semua kena } \\
\text { getahnya" } \\
\text { "Tanam cempedak, } \\
\text { tumbuh nangka" }\end{array}$ \\
\hline 8. & Durian & $\begin{array}{l}\text { "Mendapat durian } \\
\text { runtuh" }\end{array}$ \\
\hline 9. & Lada & "Belum tau dipedas lada" \\
\hline 10. & Limau & $\begin{array}{l}\text { "Kalah limau oleh } \\
\text { benalu" }\end{array}$ \\
\hline
\end{tabular}

Adapun tumbuhan monokotil yang digunakan dalam peribahasa Indonesia meliputi bambu, mentimun, padi, rumput, tebu, mawar, pisang, jagung, kelapa, kunyit, dan sirih.

Tabel 3 Nama-nama Tumbuhan Monokotil yang digunakan dalam Peribahasa Indonesia

\begin{tabular}{|c|c|c|}
\hline No. & $\begin{array}{l}\text { Tumbuhan } \\
\text { Dikotil }\end{array}$ & Peribahasa \\
\hline 1. & Bambu & $\begin{array}{l}\text { "Seperti pohon bambu } \\
\text { ditiup angin" } \\
\text { "Bagai berteduh } \\
\text { dirumpun bambu" }\end{array}$ \\
\hline 2. & Mentimun & $\begin{array}{l}\text { "Seperti mentimun } \\
\text { dengan durian" }\end{array}$ \\
\hline 3. & Padi & $\begin{array}{l}\text { "Ingat akan ilmu padi, } \\
\text { kian berisi kian } \\
\text { menunduk" } \\
\text { "Padi ditanam tumbuh } \\
\text { ilalang" } \\
\text { "Padi segenggam dengan } \\
\text { senang hati, lebih baik } \\
\text { dari pada selumbung } \\
\text { dengan bersusah hati" }\end{array}$ \\
\hline 4. & Rumput & "Bicara rumput di \\
\hline
\end{tabular}




\begin{tabular}{|c|c|c|}
\hline & & $\begin{array}{l}\text { halaman orang, di } \\
\text { halaman sendiri rumput } \\
\text { sampai kekaki tangga" } \\
\text { "Bagai embun diatas } \\
\text { rumput" }\end{array}$ \\
\hline & Tebu & $\begin{array}{lr}\text { "Seperti } & \text { tebu airnya } \\
\text { dimakan } & \text { ampasnya } \\
\text { dibuang" } & \end{array}$ \\
\hline 6. & Mawar & $\begin{array}{l}\text { "Arang itu walau dibasuh } \\
\text { dengan air mawar } \\
\text { sekalipun tetap tiada } \\
\text { putih" }\end{array}$ \\
\hline 7. & Pisang & $\begin{array}{l}\text { "Awak menangis diberi } \\
\text { pisang" }\end{array}$ \\
\hline 8. & Jagung & $\begin{array}{l}\text { "Berjagung-jagung } \\
\text { sementara padi belum } \\
\text { masak" } \\
\text { "Bagai pipit menelan } \\
\text { jagung" }\end{array}$ \\
\hline & Kelapa & $\begin{array}{l}\text { "Tua kelapa, makin tua } \\
\text { banyak santannya" }\end{array}$ \\
\hline & Kunyit & $\begin{array}{l}\text { "Kuning oleh kunyit, } \\
\text { hitam oleh arang" } \\
\text { "Bagai kunyit dengan } \\
\text { kapur" }\end{array}$ \\
\hline & Sirih & $\begin{array}{l}\text { "Ada sirih hendak makan } \\
\text { sepah" } \\
\text { "Bagai sirih diikat } \\
\text { dengan gangangnya" }\end{array}$ \\
\hline
\end{tabular}

\section{B. Intepretasi Metafora Tumbuhan dalam Peribahasa Indonesia}

Peribahasa yang dibahas dalam artikel ini adalah peribahasa yang menggunakan nama tumbuhan sebagai pembanding. Nama-nama tumbuhan dapat menggambarkan keadaan atau karakter dari seseorang, dapat pula menggambarkan suatu keadaan atau perihal.

Seperti yang telah dijelaskan sebelumnya bahwa metafora memiliki dua komponen, yaitu target dan sumber. Sumber merupakan konsep yang dijadikan dasar konseptualisasi dan target merupakan konsep dimana konseptualisasi diarahkan. Target biasanya lebih abstrak dan sumber lebih konkrit. Untuk dapat memahami maksud yang terkandung dalam metafora ditemukan kesamaan karakteristik yang dimiliki antara target dan sumber. Dengan membandingkan karakteristik yang dimiliki keduanya, maka ditemukan dasar suatu metafora digunakan. Selain itu kesamaan tidak selalu menjadi dasar untuk menunjukkan hubungan antara target dengan sumbernya, namun konseptualisasi yang berkorespondensi antara target dan sumberlah yang lebih ditonjolkan (Nirmala, 2014).

Proses kognitif dalam ungkapan metaforis dapat ditunjukkan melalui konseptualisasi yang didasarkan pada pengalaman tubuh, sifat, ciri, fungsi, dan kekuatan yang dimiliki oleh ranah sumber yang berkorespondensi dengan ranah target (Nirmala, 2014). Berikut ini merupakan hasil dari intepretasi makna metafora tumbuhan dalam peribahasa Indonesia.

\section{a) Peribahasa yang menggambarkan tumbuhan sebagai tanda kekuatan dan kelemahan}

Peribahasa yang menggunakan unsur-unsur tumbuhan dapat menggambarkan kekuatan dan kelemahan. Kekuatan dan kelemahan yang dimaksud adalah dasar dari asosiasi yang digunakan untuk menggambarkan sesuatu. Misalnya, cabai rawit merupakan tanaman yang mengindikasikan kekuatan atau akar lapuk yang menggambarkan kelemahan. 
1) "Bergantung pada akar lapuk"

\section{Ranah sumber}

Bergantung pada akar lapuk

\section{Ranah target}

Mencari pertolongan kepada orang yang lemah

Peribahasa bergantung pada akar lapuk menggambarkan orang yang meminta bantuan kepada orang yang lemah. Peribahasa ini menggunakan klasifikasi bagian dari tumbuhan yaitu akar lapuk sebagai ranah sumber. Ranah sasarannya adalah orang yang lemah. Relasi asosiasi antara ranah sumber dan ranah target adalah kekuatan.

Akar merupakan bagian dari tumbuhan yang berfungsi sebagai media mendapatkan makanan. Akar yang masih muda dapat menyerap makanan dengan baik sedangkan akar lapuk adalah akar yang sudah tua atau sudah rusak. Akar yang sudah rusak tidak dapat menjalankan fungsinya dengan baik.

Peribahasa bergantung pada akar lapuk mengindikasikan metafora +orang yang lemah adalah akar lapuk. Proses kognitif yang terjadi adalah konseptualisasi bahwa orang yang lemah dibayangkan sama dengan akar yang lapuk. Apabila kita bergantung kepada orang yang lemah berarti kita tidak akan mendapatkan pertolongan apa-apa.

2) "Kecil-kecil cabai rawit"

\section{Ranah sumber}

Kecil-kecil cabai rawit

\section{Ranah target}

Biarpun kecil tapi pemberani

Peribahasa kecil-kecil cabai rawit menggambarkan orang yang kecil tapi pemberani. Peribahasa ini menggunakan klasifikasi tumbuhan dikotil yaitu cabai rawit sebagai ranah sumber. Relasi asosiasi yang digunakan adalah rasa atau pengalaman tubuh khususnya indra pengecap.

Cabai rawit merupakan sejenis cabai yang memiliki bentuk yang mungil. Cabai rawit memiliki rasa yang sangat pedas. Rasa pedas yang dimiliki cabai rawit mengiaskan keberanian. Seseorang yang memiliki tubuh yang kecil namun sangat berani selalu dikiaskan dengan peribahasa, "kecil-kecil cabai rawit."

Kecil-kecil cabai rawit mengindikasikan metafora +orang yang kecil tapi pemberani adalah cabai rawit. Terjadi konseptualisasi bahwa orang yang kecil tapi pemberani adalah cabai rawit yang memiliki bentuk yang kecil tapi memiliki rasa yang begitu pedas.

Peribahasa (1) dan (2) tersebut menggambarkan tumbuhan sebagai tanda kekuatan dan kelemahan. Akar lapuk dikonseptualisasi sebagai kelemahan yang didasarkan pada sifat akar lapuk yang mudah jatuh dan patah. Sedangkan cabai rawit dikonseptualisasikan dengan kekuatan berdasarkan rasa/indra pengecap dari pencipta peribahasa.

b) Peribahasa yang menggambarkan

tumbuhan sebagai tanda
pembinaan sifat terpuji

Peribahasa yang menggunakan unsur-unsur tumbuhan juga dapat digunakan sebagai tanda pembinaan sifat terpuji. Hal yang dimaksudkan adalah bahwa peribahasa-peribahasa tersebut memiliki makna yang berkaitan dengan 
kebaikan-kebaikan. Berikut ini merupakan contoh peribahasa yang menggambarkan tumbuhan sebagai tanda pembinaan sifat terpuji.

3) "Sebab buah dikenal pohonnya"

\section{Ranah sumber}

Sebab buah dikenal pohonnya

Ranah target

Tabiat seseorang bisa diketahui dengan melihat perbuatannya

Peribahasa sebab buah dikenal pohonnya menggambarkan bahwa tabiat seseorang bisa diketahui dengan melihat perbuatannya. Peribahasa ini menggunakan buah dan pohon sebagai ranah sumber. Ranah target dalam peribahasa ini adalah tabiat dan perbuatan.

Buah dan pohon merupakan dua hal yang saling berkaitan, misalnya buah durian, orang akan tahu jika itu pohon durian karena melihat ada buah durian yang dihasilkan.

Peribahasa sebab buah dikenal pohonnya mengindikasikan metafora +buah adalah tabiat, +pohon adalah perbuatan. Ada proses kognitif yang terjadi yaitu: konseptualisasi bahwa buah dibayangkan dengan tabiat dan pohon dibayangkan dengan perbuatan. Tabiat atau sifat seseorang dapat dikenali dari perbuatan orang tersebut. Orang yang bertabiat pemurah dapat dilihat dari perbuatannya yang suka memberi.

Peribahasa ini menggambarkan tumbuhan sebagai tanda pembinaan sifat terpuji yaitu menjaga perbuatannya.

4) "Seperti pohon bambu ditiup angin" Ranah sumber
Seperti pohon bambu ditiup angin

\section{Ranah target}

Orang yang tetap pendirian dan tabah

Peribahasa seperti pohon bambu ditiup angin menggambarkan orang yang memiliki pendirian. Peribahasa ini menggunakan bambu sebagai ranah sumber dan orang yang tetap pendirian sebagai ranah target. Relasi asosiasi yang digunakan adalah sifat.

Bambu tumbuhan berumpun. Daunnya rimbun. Kalau pohon bambu ditiup angin, pohon bambu itu akan meliuk-liuk, kadang-kadang kalau anginnya agak kencang, bambu itu akan merunduk. Tetapi, bila angin itu telah lalu, pohon bambu itu akan tegak kembali. Orang yang tetap pendirian dan tabah menghadapi tantangan hidup. Bila kesusahan telah lewat, ia akan menegakkan kepalanya kembali.

Peribahasa ini mengindikasikan metafora +pohon bambu adalah orang yang tetap pendiriannya. Konseptualisasi antara pohon bambu dan sifat tetap pendirian. Pencipta peribahasa membayangkan pohon bambu yang ditiup angin seperti orang tetap pendirian dan tabah menghadapi hidup yang tidak menentu.

5) "Ingat akan ilmu padi, kian berisi kian menunduk"

\section{Ranah sumber}

Ingat akan ilmu padi, kian berisi kian menunduk

\section{Ranah target}

Orang tinggi ilmu semakin rendah hati 
Peribahasa ingat akan ilmu padi,
kian berisi kian menunduk menggambarkan orang yang berilmu tinggi akan semakin merendah. Peribahasa ini menggunakan padi sebagai ranah sumber dan rendah hati sebagai ranah target.

Peribahasa ingat akan ilmu padi, kian berisi kian menunduk mengindikasikan metafora +padi yang berisi adalah orang yang rendah hati. Proses kognitif yang terjadi adalah: padi yang berisi dibayangkan dengan orang yang rendah hati yang menunduk tidak tegak ketika penuh ilmu.

Padi yang berisi pati akan runduk, tetapi padi yang hampa (terserang hama) tangkainya tegak saja. Padi diumpamakan dengan orang yang pandai, kepalanya penuh ilmu. Orang yang berilmu itu dibandingkan dengan padi yang berisi selalu runduk. Sifat runduk pada padi dikiaskan kerendahan hati, karamahan. Jadi, orang yang pandai, yang berilmu, biasanya tidak sombong. Makin pandai kita hendaknya makin rendah hati.

Peribahasa (3), (4), dan (5) merupakan peribahasa yang menggambarkan tumbuhan sebagai tanda pembinaan sifat terpuji, yaitu menjaga perbuatan baik, berpendirian kuat, dan menjaga sifat rendah hati.

\section{c) Peribahasa yang menggambarkan tumbuhan sebagai tanda rejeki}

Peribahasa yang menggunakan unsur tumbuhan dapat menunjukkan tanda rejeki. Tanda rejeki yang muncul dari penafsiran terhadap metafora tumbuhan karena munculnya asosiasi tumbuhan tertentu dengan rejeki. Misalnya pada buah durian yang diasosiasikan dengan rejeki yang besar. Berikut ini merupakan contoh peribahasa yang menggambarkan rejeki.

6) "Ada batang cendawan tumbuh"

\section{Ranah sumber}

Ada batang cendawan tumbuh

Ranah terget

Setiap makhluk memiliki rejeki dimana pun berada

Peribahasa ada batang cendawan tumbuh menggambarkan bahwa setiap makhluk akan mendapatkan rejeki dimanapun dia berada. Cendawan memiliki sifat parasit atau tidak bisa hidup tanpa ada bantuan dari tumbuhan lain. Cendawan mendapatkan makanan dari tumbuhan tersebut. Dengan demikian, pada batang yang roboh pun cendawan dapat tumbuh. Peribahasa tersebut menggambarkan bahwa manusia akan mendapatkan rejeki dimanapun dia berada. Meskipun berada di tempat yang kurang layakpun manusia pasti akan mendapatkan rejekinya.

Konseptualisasi peribahasa di atas menyamakan konsep batang dengan konsep tempat hidup dan cendawan dengan konsep manusia yang lemah. Metafora yang ada adalah +batang adalah rejeki, +cendawan adalah manusia lemah.

7) "Mendapat durian runtuh" (rejeki) Ranah sumber Mendapat durian runtuh. Ranah target Mendapatkan rejeki yang tak disangka-sangka. 
Peribahasa mendapat durian runtuh menggambarkan mendapatkan rejeki yang tak disangka-sangka. Ranah sumbernya adalah durian dan ranah targetnya adalah rejeki.

Peribahasa ini mengindikaskan metafora +durian adalah rejeki. Proses kognitif yang terjadi yaitu: durian disamakan dengan rejeki. Mendapatkan durian runtuh berarti mendapatkan rejeki yang tak pernah disangka.

Durian merupakan buah yang memiliki rasa yang sangat lezat. Selain cita rasanya, buah durian dikenal sebagai buah yang harganya mahal. Biasanya, hanya orang yang memiliki uang yang cukup yang dapat membeli buah durian. Jika mendapatkan durian dengan cara durian tersebut runtuh berarti mendapatkan rejeki yang tak disangkasangka.

Peribahasa

(6) dan

menggambarkan tumbuhan sebagai tanda rejeki, yaitu batang dan durian.

\section{d) Peribahasa yang menggambarkan tumbuhan sebagai tanda hidup sederhana}

Peribahasa yang menggunakan unsur tumbuhan memiliki penafsiran sebagai tanda hidup sederhana. Masyarakat Indonesia diajarkan lewat tumbuh-tumbuhan di sekitarnya mengenai nilai kebajikan seperti hidup sederhana. Berikut ini merupakan contoh peribahasa yang menggambarkan nilai tersebut.

8) "Tiada rotan akarpun jadi"

Ranah sumber

Tiada rotan akarpun jadi

Ranah target
Apabila tidak ada barang yang bagus barang yang tidak begitu bagus bisa digunakan.

Peribahasa tiada rotan akarpun jadi menggambarkan bahwa jika tidak ada barang yang berkualitas bagus, barang yang berkualitas di bawahnya masih bisa digunakan.

Peribahasa di atas membandingkan dua jenis bahan, yaitu akar dan rotan. Secara kualitas, rotan dianggap lebih baik dibandingkan dengan akar. Akar biasa digunakan ketika rotan tidak ada. Rotan dan merupakan hal yang abstrak. Rotan dikonkritkan dengan barang yang berkualitas baik sedangkan akar adalah barang yang berkualitas kurang baik atau kualitas yang lebih rendah dari barang satunya. Seringkali dalam kehidupan sehari-hari kita tidak selamanya menemukan barang yang berkualitas baik, enak dipakai, atau baik hasilnya. Bila kita tidak menemukan barang tersebut, maka barang dengan kualitas di bawahnya bisa kita gunakan. Misalkan kita ingin makan ayam goreng tetapi ternyata di dalam kulkas hanya ada tahu/tempe. Maka kita bisa memakan tahu atau tempe tersebut.

9) "Berjagung-jagung sementara padi belum masak"

Ranah sumber

Berjagung-jagung sementara padi belum masak

\section{Ranah target}

Sementara belum ada yang lebih baik, baiknya yang belum begitu baik yang digunakan 


\section{Peribahasa \\ berjagung-jagung \\ sementara padi belum masak} menggambarkan Sementara belum ada yang lebih baik, baiknya yang belum begitu baik yang digunakan. Peribahasa ini menggunakan ranah sumber jagung dan padi. Relasi asosiasi yang digunakan adalah fungsi.

Padi apabila sudah masak jadilah nasi. Nasi merupakan makanan pokok masyarakat Indonesia. Nasi merupakan sumber karbohidrat. Selain nasi, jagung merupakan sumber karbohidrat. Namun, masyarakat Indonesia tidak terbiasa hanya makan jagung. Masyarakat Indonesia mengenal nasi sebagai makanan pokok yang tidak bisa digantikan oleh jenis bahan yang memiliki sumber karbohidrat yang sama. Maka, orang Indonesia mengenal istilah, "belum makan jika belum makan nasi".

Peribahasa di atas menggambarkan bahwa apabila belum ada barang/hal utama yang kita dapatkan maka hal yang lain bisa digunakan. Peribahasa ini menunjukkan bahwa kita harus hidup sederhana, jika tidak ada barang bagus yang dimiliki, barang yang ada bisa digunakan walaupun tidak sebagus yang diinginkan.

\section{e) Peribahasa yang memaparkan tumbuhan sebagai tanda keburukan}

Peribahasa yang menggunakan unsur tumbuhan tidak hanya berisi nilainilai kebaikan yang perlu untuk dicontoh namun juga menggandung hal-hal buruk yang berfungsi sebagai nasihat atau sindiran. Berikut ini merupakan peribahasa yang menggambarkan tumbuhan sebagai tanda keburukan.

\section{0) "Seperti duri dalam daging" \\ Ranah sumber \\ Seperti duri dalam daging \\ Ranah terget \\ Tidak menyenangkan hati}

Peribahasa seperti duri dalam daging menggambarkan sesuatu atau seseorang yang tidak menyenangkan hati. Peribahasa ini menggunakan klasifikasi duri sebagai ranah sumber. Relasi asosiasi yang digunakan adalah indra perasa.

Secara denotasi, duri merupakan bagian dari tumbuhan yang apabila bagian tubuh kita terkena duri maka akan terasa sakit. Apabila kaki kita kemasukan duri, kemudian duri tersebut tidak segera dikeluarkan, maka kaki kita akan bengkak dan terasa sakit. Kaki kita selamanya akan terasa sakit apabila duri tersebut tidak kita keluarkan. Peribahasa tersebut menggambarkan duri sebagai metafora +duri adalah hal yang menyakitkan hati. Jadi, apabila ada sesuatu yang menyakitkan tersimpan di dalam hati, maka apabila dikenang akan selalu menyakitkan hati. Misalnya ada seseorang yang telah menyakiti hati kita dengan menghina atau memaki kita, selama orang tersebut belum meminta maaf maka kita akan selalu merasa sakit jika bertemu atau berkomunikasi dengan orang tersebut.

11) "Bila siang hari, lupa kacang pada kulitnya"

Ranah sumber

Bila siang hari, lupa kacang pada kulitnya

Ranah target 
Melupakan jasa orang yang membantu

Peribahasa bila siang hari, lupa kacang pada kuitnya menggambarkan melupakan jasa orang yang membantu. Peribahasa ini menggunakan kacang dan kulit sebagai ranah sumber. Kacang buahnya terbungkus oleh kulit. Kalau kacang itu kita jemur berhari-hari di panas matahari, kulitnya pecah dan ada kemungkinan bijinya akan lepas dari kulit itu. Kulit berfungsi menjaga biji kacang agar tidak mudah rusak. Kulit kacang berguna bagi biji kacang.

Peribahasa di atas menggambarkan kacang sebagai tanda dari sifat tidak terpuji, yaitu melupakan jasa orang yang telah membantu. Peribahasa ini mengindikasikan metafora +kacang adalah orang yang melupakan jasa orang lain.

\section{SIMPULAN}

Leksikon tumbuhan banyak digunakan dalam peribahasa Indonesia. Beraneka ragam tumbuhan yang terdapat di tanah Indonesia menginspirasi pencipta peribahasa untuk menggunakan tumbuhan sebagai metafora yang menggambarkan hikmah atau nilai-nilai tertentu kepada masyarakat. Maka, peribahasa Indonesia menggunakan ranah tumbuhan untuk menggambarkan sesuatu yang abstrak agar lebih bersifat konkrit. Pengalaman berkaitan dengan sifat, ciri, dan bentuk dari tumbuhan memunculkan bahasa figuratif, khususnya metafora untuk menggambarkan hal-hal tertentu. Tumbuhan-tumbuhan yang digunakan dalam peribahasa yaitu 1) bagian-bagian tumbuhan meliputi biji, akar, batang, dahan, daun, dan bunga; 2) klasifikasi tumbuhan berdasarkan bijinya, yaitu tumbuhan dikotil dan tumbuhan monokotil. Tumbuhan dikotil meliputi delima, kacang, kopi, nangka, ubi, cabai, cempedak, durian, limau, dan lada; sedangkan tumbuhan monokotil yaitu bambu, mentimun, padi, rumput, tebu, mawar, pisang, jagung, kelapa, kunyit, dan sirih.

Mekanisme semantik kognitif terjadi dalam metafora tumbuhan dalam peribahasa Indonesia. Intepretasi dari peribahasa tumbuhan yaitu tumbuhan sebagai tanda kekuatan dan kelemahan, tumbuhan sebagai tanda sifat terpuji, tumbuhan sebagai tanda hubungan persaudaraan, tumbuhan sebagai tanda rejeki, tumbuhan sebagai tanda hidup sederhana, dan tumbuhan sebagai tanda keburukan.

\section{UCAPAN TERIMA KASIH}

Artikel ini merupakan artikel berdasarkan penelitian yang dilaksanakan tahun 2018 dengan anggaran Direktorat Riset dan Pengabdian Masyarakat (DRPM). Oleh karena itu ucapan terima kasih disampaikan kepada Kementerian Ristek DIKTI yang telah mendanai penelitian ini. Selanjutnya, ucapan terima kasih disampaikan kepada reviewer yang telah mengoreksi dan memberi masukan artikel ini.

\section{DAFTAR PUSTAKA}

Abdullah, Imran-Ho. 2011. "Analisis Kognitif Semantik Peribahasa Melayu 
Bersumber Anjing (Canis Familiaris)". Dalam jurnal IImiah GEMA Online Journal of Languange Studies. Vol. 11. No. 1. (Online), diakses 23 Maret 2017.

Badudu, J.S. 2009. Kamus Peribahasa. Jakarta: PT Gramedia.

Bagea, Ishak. 2013. "Metafora dalam Wacana Pinggitan Pada Masyarakat Mawasangka Kabupaten Butonn Provinsi Sulawesi Tenggara (Suatu Tinjauan Linguistik Antropologis)." Disertasi (tidak diterbitkan). Universitas Gadjah Mada.

Danandjaya, James. 1984. Folklore Indonesia, IImu Gosip, Dongeng dan lain-lain. Jakarta: Gratipers.

Kurnia, Ermy Dyah. 2016. Metafora Binatang dalam Peribahasa Jawa. Prosiding. International Seminar Prasasti III; 283-287.

Konvesces, Zoltan. 2002. Metaphor: A Practical Introduction. New York: Oxford University Press Inc. Lakoff, George dan Mark Johnson. 1980. Metaphors We Live By. Chicago: The University of Chicago Press.
Nirmala, Deli. 2014. "Proses Kognitif dalam Ungkapan Metaforis". Dalam Jurnal IImiah PAROLE VOL.4 NO. 1, April 2014. Semarang: Universitas Diponegoro.

Pateda, Mansoer. 2001. Semantik Leksikal. Edisi Kedua. Jakarta: Rineka Cipta.

Sibarani, Robert. 2004. Antropologi Linguistik, Linguistik Antripologi. Medan: Poda.

Sudaryanto. 1993. Metode dan Aneka Teknik Analisis Bahasa: Pengantar Penelitian Wahana Budaya secara Linguistik. Yogyakarta: Duta Wacana University Press.

Wijana, I Dewa Putu \& Muhammad Rohmadi. 2008. Semantik:Teori dan Analisis. Cetakan Pertama. Surakarta: Yuma Pustaka.

Wasri, Mohammad Kusnadi. 2007. Kumpulan Peribahasa. Lingkar Media. 